\title{
Technology Entrepreneurship in Emerging Markets: An Exploration of Entrepreneurial Models Prevalent in India
}

\author{
Shiv S Tripathi and Mita Brahma
}

\author{
"In the business world, the rear-view mirror") \\ is always clearer than the windshield. \\ Warren Buffett \\ Business magnate, investor, and philanthropist
}

\begin{abstract}
Are the features and processes of entrepreneurship - such as wealth creation, risk taking, vision, identification of a niche market, launching new products, and so on - common across the world? Many would assume they would be. However, firms that are entrepreneurial in nature and belong to emerging markets may or may not follow the established models of developed economies. In this study, we sought to explore various types of entrepreneurial models that are prevalent in an emerging market. For this purpose, we collected primary and secondary data to identify characteristics of technology-based entrepreneurial firms in India. Based on the two dimensions of degree of demand/supply and expected loss/risk, we identify four models of entrepreneurship - incremental, proactive, radical, and reactive - and illustrate each model with examples from Indian companies.
\end{abstract}

\section{Introduction}

In this article, we revisit theories of entrepreneurship to explore some of the unique features of technology entrepreneurship and how they may interact with the distinctive features of emerging markets. With the help of inputs from practicing business models and 20 personal interviews with technology entrepreneurs, we propose a framework that describes how the various technology entrepreneurship models in emerging countries are derived.

A successful venture creates wealth for its entrepreneurial team and it creates value in the marketplace (Sarasvathy, 2001). However, technology has changed both the perspectives on uncertainty in new ventures, as well as the estimates of outcomes. Crowdfunding and digital marketplaces have created a platform where available resources, capabilities, constraints, and risks are redefined. Technology has simultaneously changed the rigid boundaries between phases of a new product or service. The outcome is dynamic, non-linear, continuously tested in the marketplace, and evolving (Nambisan, 2017).
Emerging markets have greater uncertainty in their political and business environments. They have greater constraints by way of economic and government policies, and in infrastructure. However, given an opportunity, the constraints can at times be surmounted by a leapfrogging technology or the use of technology to develop a new business model. Emerging markets present highly skilled and low-cost labour; unmet needs of the consumer; and differing buyer behaviour in diverse segments. They present challenges of finding early adopters, marketing and distribution issues, and low-price points. The firms that succeed do not follow the established business models of the developing economies. They succeed by finding innovative methods of aggregating the demand or supply, or of making access or usage easier for the customer, by using innovative business models (Thukral et al., 2008).

Following the opening up of the economy, and the subsequent rapid expansion of the mobile and Internet sector in India, there has been a surge in the number of startups being established in the country. Most of these startups use technology as an enabler. Therefore, in this study, our approach was to look out for patterns in 


\section{Technology Entrepreneurship in Emerging Markets: An Exploration of Entrepreneurial Models Prevalent in India Shiv S Tripathi and Mita Brahma}

the entrepreneurial models of some of these firms using technology at the core of their business model. We collected primary and secondary data to identify the characteristics of entrepreneurial firms in the technology domain only. We compared and contrasted the business models of these firms with models of developed markets, and we developed a framework to position these models. Overall, this framework is intended to represent the types of entrepreneurial models of emerging market firms whose core enabler of business model is technology as compared to any other resource.

\section{Entrepreneurial Models and Technology Entrepreneurship}

Most entrepreneurial research in developed nations has focused on new venture creation. The dimensions explored are the environment in which the venture gets created, the individual(s) creating the venture, the process of its creation, and the type of venture itself. Research has focused on the process of identification and exploitation of opportunities as being at the heart of the entrepreneurial process. Researchers have explored how, why, and when opportunities come into existence. Why, when, and how some people discover these opportunities and not others. And, out of these, why, when and how, some entrepreneurs (and not others) exploit the opportunities. The venture-creation process that followed opportunity identification and the performance of the business venture were in a sense, consequences of the opportunity-discovery activity (Shane \& Venkataraman, 2000).

Factors such as prior knowledge - of markets, of technologies, of customers and of business processes - have been explored as factors contributing to the opportunity-recognition process (Shane, 2000). These explorations reiterated the position of individual entrepreneurs and entrepreneurial teams as being pivotal to the opportunity identification process. The processes following opportunity recognition and identification are usually to do with planning and designing, gathering resources, identifying customers and markets, producing and selling the product, while building the organization and managing regulatory processes (Gartner, 1985). The effectuation process, however, starts on a different note, with the process of identifying the available means of evaluating constraints and of exploring alternatives, while keeping risks and losses at an affordable level. This process works more often in dynamic and non-linear environments. The entrepren- eurs look for alliances as a method to manage uncertainties in the future, to create markets, and to build cooperative allies for contingencies (Sarasvathy, 2001).

As a specific type of entrepreneurship, technology entrepreneurship is defined as "an investment in a project that assembles and deploys specialized individuals and heterogeneous assets that are intricately related to advances in scientific and technological knowledge for the purpose of creating and capturing value for a firm" (Bailetti, 2012), and at its heart is the establishment of new technology ventures. Individual technology entrepreneurs have been categorized as researchers, producers, users and opportunists as per their technical orientation and background. However, technology entrepreneurs are often a mix of these attributes. Also, entrepreneurial teams have a combination of these attributes (Jones-Evans, 1995). Technology entrepreneurs differ in the ways in which they draw on resources and structures to exploit technology opportunities. They may focus on self-dependency or on the right network and alliances (Tzu-Hsin et al., 2005).

The process of technology entrepreneurship is about recognizing, creating, and exploiting opportunities, and assembling resources around a technological solution, irrespective of the organizational context (Bailetti, 2012; Ratinho et al., 2015; Spiegel \& Marxt, 2011). The technological solution opens up new possibilities, it allows the reduction of transactional costs (Williamson, 2005), and it has the ability to use new a technology product paradigm to provide a solution to a market gap (Ratinho et al., 2015). Technology entrepreneurship differs from general entrepreneurship in that it focuses on technological opportunities that require deep technological as well as managerial capabilities (Prahalad \& Hamel, 1990; Walsh \& Linton, 2011). In other words, it requires a higher level of technical capabilities and management of a risky environment (Harms \& Walsh, 2015). Alternatively, it involves the same opportunity identification, organization, and execution found in any other form of entrepreneurship but around a focused technology and a business model that makes it unique.

\section{Entrepreneurship in Emerging Markets}

Entrepreneurship is found to contribute to wealth creation and poverty alleviation in nations. By creating disruptive influences, it contributes to a better wealth distribution in the country. It creates jobs and improves the standards of living. It addresses gender inequality in 


\section{Technology Entrepreneurship in Emerging Markets: An Exploration of Entrepreneurial Models Prevalent in India Shiv S Tripathi and Mita Brahma}

the process. It also builds a better balance for regional economic development indices (Noel \& Banerjee, 2014). However, in an analysis of $R \& D$ spend as a percentage of GDP, India ranked far behind China, Brazil, and Singapore (UNESCO, 2018). Thus, the science, technology, and innovation policy of India has identified measures to improve a national knowledge network, infrastructure, and investments. It includes measures such as enrichment of the knowledge base; incentivizing $R \& D$ in the public and private sectors; improving governance in science and technology institutions; fostering collaboration between academia, industry, and scientific establishments; promoting collaboration through clusters; supporting the financial system; providing a platform for best practices and innovations; improving the flow of technology; developing and protecting intellectual property rights; and implementing geographic information systems (Planning Commission of India, 2018).

In terms of entrepreneurship, less than $16 \%$ of the Indian population within the 18-64 age group were found to be engaged in entrepreneurial activity, as compared to $41 \%$ percent in China, and $48 \%$ percent in Brazil (Chaurasia \& Bhikajee, 2016). In India, some of the factors that inhibit entrepreneurship are: its caste system, its cultural values that affect the acceptability and utility of entrepreneurship, and governmental regulations that have a monitoring and control perspective (Dana, 2000). On the other hand, the Indian entrepreneur is known for "jugaad", or frugal innovation. Consumers, governments, and organizations benefit from the practice of such flexible and inclusive forms of innovation to be able to find sustainable solutions (Prabhu \& Jain, 2015), especially in an emergent market such as India.

Emerging markets present a significant growth potential, with a positive and significant growth rate of gross domestic product, and growing aspirations of their people. However, they present unique challenges as well. To build sustainable solutions in keeping with the varying needs of different socio-economic segments, products and services have to build on greater knowledge from the customer. As per Goyal and colleagues (2017), some of the approaches companies in emerging markets have taken are:

1. Leverage volume-based cost efficiencies because they increase market share. This approach involves sufficient value creation for the given market segment.
2. Bundle offerings in various innovative ways to suit different pockets, and thus to capture different tiers of the market.

3. Separate and unbundle various business processes into separate units. This allows organizations to focus on processes relating to their core competencies, and thus drives efficiency.

4. Follow open innovation of both types: "outside in" by using external ideas and research and "inside out" by licensing or sharing internal innovation ideas and products.

5. Follow a "hub and spoke" arrangement of infrastructure and business services, with the smaller spokes in the less accessible and less developed areas.

6. Use crowdsourcing and grow a network of multiple suppliers. This builds safeguards for contingencies and also reduces dependence on key resources.

7. Offer "price-minus" or "challenge-cost" pricing. This involves working out a suite of features for a product to match the paying capacity of the buyer while at the same time creating a value proposition.

Furthermore, research by Majumdar and co-authors (2010) on 876 firms in the Indian software industry found that, on one hand, the more dominant firms undertake higher-margin activities. The less powerful firms, on the other hand, follow a more uncertain path, with lower revenues per employee.

\section{Method}

We contacted 20 technology entrepreneurs in India and asked about their current business, how they had identified opportunities, what motivated them to pursue these opportunities, and how they continuously adapted their business with feedback from associates, as suggested by Karlesky (2015). A discussion guide was used for this purpose, and we found that we reached theoretical saturation with 20 respondents.

Technology entrepreneurship firms have been broadly explored in the literature as per the themes of the environmental factors influencing them, the strategies deployed, and processes of organizing their resources and technologies (Shane \& Venkataraman, 2003). The four control variables to select the firms in this research were: i) they were using technology as the core of their 


\section{Technology Entrepreneurship in Emerging Markets: An Exploration of Entrepreneurial Models Prevalent in India Shiv S Tripathi and Mita Brahma}

business model; ii) they had a presence throughout India; iii) they were successful; and iv) they must have been in operation for at least the past 3 years. The firms explored in this research belonged to the following domains: information technology; travel and entertainment; embedded systems; cloud computing; and the banking, financial services, and insurance sectors. All were technology-based entrepreneurial firms that operated in urban and semi-urban India. Here, technologybased entrepreneurial firms means those companies that use technology (i.e., proprietary technology, including single-sided or multi-sided platforms) at the core of their business model. It means that, if one removes the technology part from the business model of these firms, they will cease to exist. Therefore, these firms used technology as their core competency and were either selling products or services themselves or provided a platform for clients and servers.

We used the theories of two classical economists towards entrepreneurship given by Joseph Schumpeter (1974), who focussed on the demand-side innovator, and the other used by Frank Knight (1964), who based his analysis predominantly on the type of risk an entrepreneur was taking to arrive at the synthesized (Leyden \& Link, 2015) model to analyze the approaches of the companies. We adopted a framework of comparing the entrepreneurship firms based on a dual approach. First, we examined the entrepreneurial firm's approach to providing technology solutions to the customer; second, we examined the entrepreneurial firm's approach to risk management in an effectuation mode. Based on their inputs followed by a content analysis of the interviews from 20 respondents using the discussion guide, the results were grouped into four approaches as described below. The responses were categorized based on the approach followed by these technology entrepreneurs to launch a new venture. In total, four themes (approaches) emerged out of the content analysis. The first approach comprised firms developing a minor yet unique value proposition using technology as the differentiator, in a market where already a number of players existed. The second approach comprised those companies who tried to capture the need of the market before anybody else could do so, distinctively keeping the entire country's market in mind. The third approach was followed by companies who disrupted the market by offering a technology solution that never existed before. A fourth approach was followed by some companies who seconded an earlier player and typically followed a "me too" strategy.

\section{Results}

For each technology firm we surveyed, we classified their use technology to create value propositions for their customers. We then classified this use along two dimensions - the degree of change brought about and the degree of risk taken - which yielded four approaches to technology entrepreneurship (Figure 1):

\section{Incremental}

\section{Proactive}

3. Radical

\section{Reactive}

As listed in Figure 1 and described in the subsections that follow, our exploratory research found examples of all four models in the firms surveyed. As entrepreneurs decide on methods of opportunity exploitation, they are guided by considerations of containing losses and covering for contingencies (Sarasvathy, 2001), and by the economic factors of demand and supply (Dawson et al., 2016). Rather than making grand plans, they make incremental plans based on their means and constraints. However, the ready availability of capital, social, and relational capital may change their risk perceptions.

\section{Incremental}

Companies in this category are based in a quadrant where the expected risk is low and the firms aim to make a small change in demand and supply. Such firms identify an existing need and develop a technology solution around it to fulfil the need in a much better way or provide for ease of use through their technology solution, all by keeping the risk levels low. The technology solution is unique, scalable, and fulfils a major existing need of the consumers. Some examples of companies belonging to this quadrant are:

- Ferns N Petals (fnp.com) is one of the largest retail chains that sells flowers and gifts. Founded in 1994 in New Delhi, India, it started with selling roses and other flowers for weddings and birthdays, at parties, and at its retail stores. Vikaas Gutgutia, the founder, did try branching off into a food business, but that was not a success. Vikaas realized he knew the flowers business best and could link up with the best people in the flowers business, assuring customers of a standard quality, something he had failed to manage in the 


\section{Technology Entrepreneurship in Emerging Markets: An Exploration of Entrepreneurial Models Prevalent in India Shiv S Tripathi and Mita Brahma}

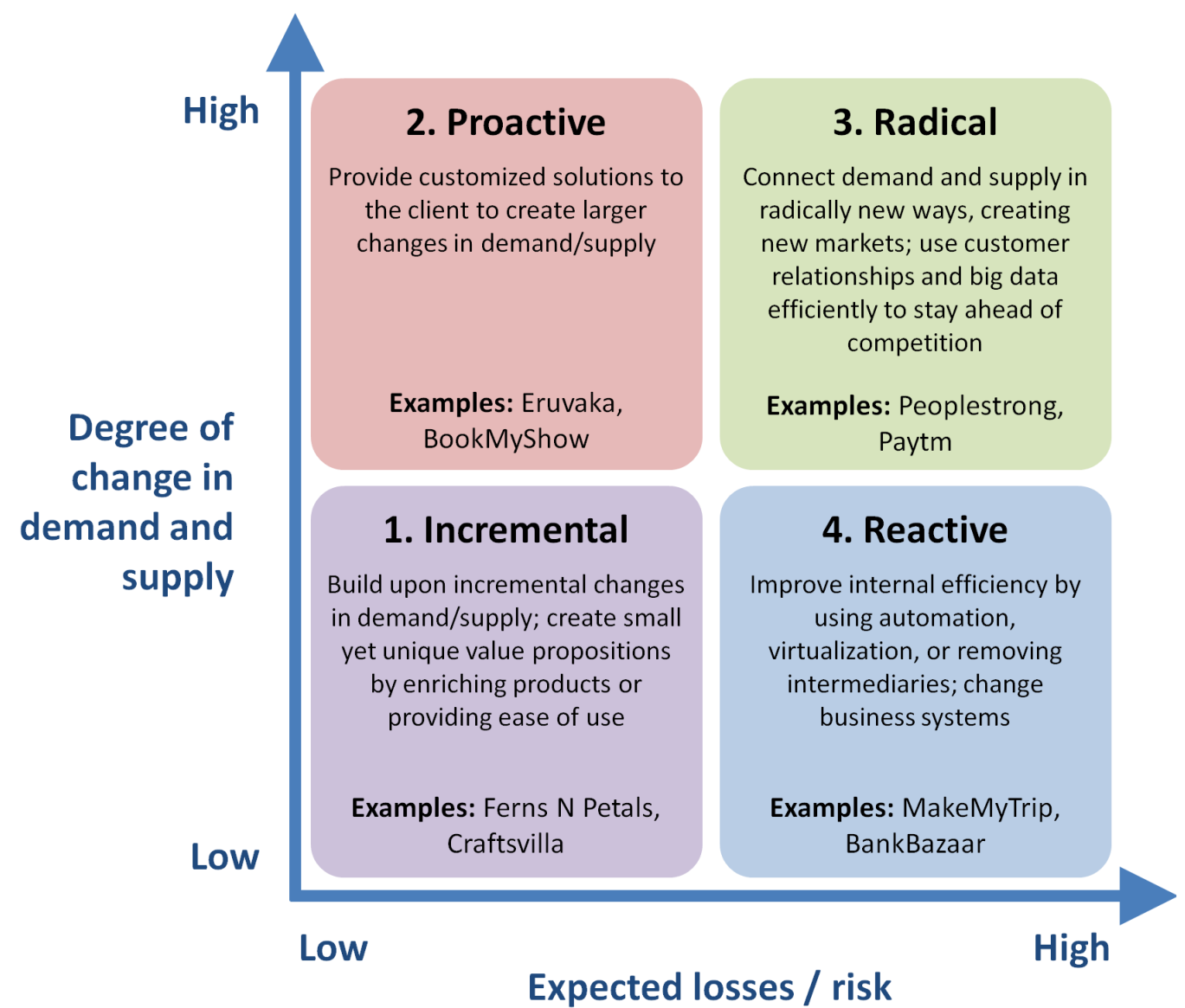

Figure 1. Models of technology entrepreneurship and examples of Indian firms for each type

food business. In 2009, Ferns N Petals revenues stood at INR 300 million (approximately $\$ 6$ million CAD), and by 2012, revenues had increased to INR 1.45 billion (\$38 million CAD) with a profit of INR 130 million (\$2.5 million CAD). Vikaas decided it was time to go global (Thomas, 2013). The company uses an e-commerce platform to take orders from and supply to cities across India and 150 countries across the globe. It has also expanded its products to other gifts, cakes, and chocolates. It takes orders online and delivers the cakes and flowers along with the sender's message fresh through its outlets across the world. It is now a truly global company, taking orders and messages from one country, and delivering to the receiver across the world.

- Craftsvilla (craftsvilla.com) is in the business of traditional apparel, accessories, beauty products, and home décor. It has successfully created an online marketplace to bring artisans, designers, and consumers together on the same platform. It was founded by Manish
Gupta and Monica Gupta in 2011 as a purely Internetbased firm. Craftsvilla has been successful in making a range of quality hand-crafted products accessible online. Buyers of crafts and apparel were slow to adopt ecommerce, but the consistent quality and service levels of Craftsvilla paid off. Also, the company has successfully cultivated a chain of vendors, and this process has helped organize the ethnic craft industry (Nexus, 2015).

\section{Proactive}

Companies in this quadrant try to provide a customized solution to the client and aim at making huge strides in terms of demand and supply. In other words, they propose massive shifts in demand and supply in a low-risk sector by focusing on an identified or hidden need based on customer problems. In the proactive model, the customer is not able to demand a solution because they are not aware that there can be a technological solution to their current problem. Some examples of proactive orientation are given below. 


\section{Technology Entrepreneurship in Emerging Markets: An Exploration of Entrepreneurial Models Prevalent in India Shiv S Tripathi and Mita Brahma}

- Eruvaka Technologies (eruvaka.com) uses artificial intelligence (AI) to monitor the data of aquaculture ponds. Sreeram Ravi, the founder, had worked in a Japanese electronics firm, manufacturing chipsets and routers. Back in his village, he came across the problem of fish dying due to depleted oxygen levels in his uncle's pond. To farm efficiently, pond owners needed to know the oxygen levels, the temperature, and the $\mathrm{pH}$ level of the water so they would then be able to take corrective action, if required. Sreeram's company now tracks this data with floating buoys that measure all the water parameters. The data is transmitted to the owner's smartphones through a cloud-based application. The application can also make a voice call or send an SMS or email to the farmer/owner. Sreeram has been growing along with his customers, understanding their needs, and tweaking his product accordingly. Sreeram believes that only technology-aided, cost-effective solutions can make agriculture sustainable and profitable. His company now provides AI-driven monitoring to the aerators in the ponds as well, thus helping the farmer save on energy bills (Chamikutty, 2014).

- BookMyShow (bookmyshow.com) is India's largest online ticketing company for movies and events. It was started in 1999 by Ashish Hemranjani and two cofounders. It currently has more than a million users. The company has made several innovations and strategic alliances. It acquired Burrp, a food technology company, to complement its movie and event business, and to provide its customers a richer experience (Your Story, 2017). Whatsapp has recently entered into a deal with BookMyShow to use it as a default ticket confirmation channel (FE Online, 2017). Whatsapp has 200 million users in India, and the collaboration will help both organizations use data more cleverly to customize their offerings to customers (Arakali, 2017). One possibility is that BookMyShow may be able to aggregate customer preferences for their choice of movie, theatre location, date and time. It has linked up with Vkaao (http://vkaao.com) to provide a web platform that allows customers to make these choices. BookMyShow plans to use data analytics to curate movies and show customers genres of movies more in line with their stated preferences (The Hindu Business Line, 2017).

\section{Radical}

These are the companies falling under the quadrant where they connect demand and supply in radically new ways, create new markets, and use existing customer relationships and big data efficiently to stay ahead of the competition. This is also a high-risk proposition, as at this stage, the client and server both are large. Suppose, for example, that the technology solution does not work or encounters issues, such as with government regulations. At the same time, another risk is creating parallel competition if the technology solution provided by them has huge potential throughout the industry and other players would like to copy it. Some examples include the following:

- Peoplestrong (peoplestrong.com) is a leading human resources (HR) solutions management company. It uses technology to provide a cloud-based product for managing HR operations from the "entry to exit" of an employee. The company has adopted five principles: i) usability: making operations simpler for the employee as well as the employer; ii) mobility: $24 \times 7$ access via applications on mobile handsets; iii) analytics: using data to provide insight; iv) cloud-based storage for security and easy access; and v) social reach: using social media and automation. The company was founded in 2005, and it is now present in over 40 Indian cities. It boasts of an impressive clientele of 175 multinational and large Indian organizations (Balakrishnan, 2017). At the time the company started, some parts of the recruitment and training processes would be outsourced. For most processes, companies were not ready to send employee data to a third-party service provider. However, Peoplestrong has not only won the trust of its clients, it has continuously innovated its services. It provides strong assessment tools and analytics to its clients as a decision support system. It has now made AI-based chatbots available to clients to answer most routine queries. This leaves HR professionals free to spend time on more strategic tasks (Singh, 2017).

- Paytm (paytm.com) is an Indian e-payments and e-commerce organization. It was founded in 2010 by Vijay Shekhar Sharma, primarily to enable mobile-to-mobile payments. In 2015, Paytm received a licence to start a payments bank. Paytm services are available through a browser and through an application operating on Windows, Android, and iOS systems. The Paytm wallet system enables users with a smartphone to access and pay for train and air tickets, taxis, mobile and electricity bills, movie and event tickets, and fuel at petrol pumps, among other uses. The company has thus facilitated cashless transactions for a large number of users. It currently has more than 3 million offline merchants and more than 200 million users in India. Paytm has now started offering a social messaging interaction among its users and merchants by integrating a chat and messaging service (Bhalla, 2017). During the celebrations of the Diwali festival in October 2017, 


\section{Technology Entrepreneurship in Emerging Markets: An Exploration of Entrepreneurial Models Prevalent in India Shiv S Tripathi and Mita Brahma}

\begin{abstract}
the company facilitated the purchase of gold through its portal by linking up with the government organization Minerals and Metals Trading Corporation. Paytm says that a million customers used the services within six months forINR 1.2 billion (approximately $\$ 23$ million CAD) worth of gold transactions (BT Online, 2017).
\end{abstract}

\section{Reactive}

Technology entrepreneurs in this quadrant typically follow the aggregator model, where they try to provide a one-stop shop to meet needs related to one particular area. For example, they may develop technology solutions that allows users to compare various insurance policies and an option to buy them, book everything related with travel, or compare the features of automobiles. Or, they may provide a logical extension of a discussion or rating forum to become an integrated solution provider in a particular domain. They are reactive in the sense that these solutions typically do not aim to provide any shift in demand and supply a "me too" solution through aggregation. The risks are higher in this case as there is typically no unique selling proposition or strategy of these players, and they act like aggregators. Some examples are given below:

- MakeMyTrip (makemytrip.com) is an Indian online travel company. Founded in 2000, it started as an organization to facilitate Indians travelling into India from abroad. Foreign travellers could manage flight tickets, hotel reservations, rail and bus tickets, and other local travel bookings. At that time, these services were provided through a maze of local travel agents. The Indian traveller was used to managing this process through local relationships. However, over time, the company managed to establish its name and remove intermediaries from many of these processes. The Indian customer, too, was simultaneously becoming more and more adept at using smart devices, and the company started its Indian operations in 2005. The company has been constantly innovating to make its mobile apps friendly for the common user. It has expanded its international operations as well. Currently, it is present in 50 cities in India and has offices in South East Asia, Europe, Australia, and the USA. In the process, it has contributed to automation in booking of all travel modes as well as in booking in the homestays market.
- BankBazaar (bankbazaar.com) was founded in 2008 by a team of six people in Chennai, India. It enables users to compare terms for offers from banks and financial services companies. Some of the products that can be compared are credit cards, insurance policies, investment funds, and loans. More than 30 banks and several insurance companies have partnered with Bankbazaar to be featured on its website and mobile platform. This allows the banks and financial services companies to target customers with loans and insurance policies on a need basis. Bankbazaar is paid by the banks and financial service providers with whom it has partnered. Customers are able to check their eligibility and their credit rating, and they can compare offerings from various organizations vis-à-vis their own needs and paying capacities. The company expanded in 2016 to Singapore and in 2017 to Malaysia (Dasgupta, 2017). Its mission is to offer customers a paperless, seamless service, and to facilitate growth for its clients dealing with financial services (Thomas \& Bhattacharya, 2017).

\section{Conclusion}

The matrix given in Figurel suggests a way to classify technology firms into four quadrants on the basis of the anticipated changes in demand and supply of that product or service and the amount of risk involved for the technology entrepreneur at the organizational level. It represents the organizational strategy and the type of business objective a technology entrepreneur is intending to focus on, assuming that the required technological capabilities pre-exist within the technology entrepreneurship firm. The model suggests a method to compare and contrast different technology ventures in India and in other emerging countries. Individual attributes that contribute to a lower or higher level of risk tolerance among entrepreneurial individuals and teams can be explored in future research. The availability of technology expertise in the founding team, human capital, knowledge of markets, and knowledge of the customer can be explored as determinants for selecting a business model to change the sources of supply, of demand, or both. The scope of this article was limited to India, but could be expanded to consider firms from other emerging markets. 


\section{Technology Entrepreneurship in Emerging Markets: An Exploration of Entrepreneurial Models Prevalent in India Shiv S Tripathi and Mita Brahma}

\section{References}

Arakali, H. 2017. BookMyshow's Experiment with WhatsApp Could Help its AI Efforts. Forbes India, September 15, 2017. Accessed December 1, 2017:

http://www.forbesindia.com/article/special/bookmyshowsexperiment-with-whatsapp-could-help-its-ai-efforts/48143/1

Bailetti, T. 2012. Technology Entrepreneurship: Overview, Definition, and Distinctive Aspects. Technology Innovation Management Review, 2(2): 5-12.

http://timreview.ca/article/520

Bhalla, T. 2017. Paytm Confirms Messaging Platform, Launches Chat Payments Feature 'Inbox'. Your Story, November 3, 2017. Accessed December 1, 2017:

https://yourstory.com/2017/11/paytm-messaging-platformlaunches-chat-payments-feature-inbox/

BT Online. 2017. Paytm Sees Gold Transactions Worth Rs. 120 Crores in 6 Months, Over 1 Million Buyers till Dhanteras. Business Today, October 18, 2017. Accessed December 1, 2017:

http://www.businesstoday.in/current/corporate/buying-gold-onpaytm-coins-transaction-dhanteras/story/262302.html

Chamikutty, P. 2014. Fishing in the Right Waters, Eruvaka Technologies. Your Story, January 5, 2014. Accessed December 1, 2017:

https://yourstory.com/2014/01/fishing-right-waters-eruvakatechnologies/

Chaurasia, R., \& Bhikajee, M. 2016. Adding Entrepreneurship to India's Science, Technology \& Innovation Policy. Journal of Technology Management \& Innovation, 11(2): 86-103. http://dx.doi.org/10.4067/S0718-27242016000200009

Dana, L. P. 2000. Creating Entrepreneurs in India. Journal of Small Business Management, 38(1): 86-91.

Dawson, A., Hirt, M., \& Scanlan, J. 2016. The Economic Essentials of Digital Strategy. McKinsey Quarterly, March 2016. Accessed December 1, 2017:

https://www.mckinsey.com/business-functions/strategy-andcorporate-finance/our-insights/the-economic-essentials-ofdigital-strategy

FE Online. 2017. WhatsApp Business App Goes Live: How to Get BookMyShow Movie Tickets Confirmation on Mobile. Financial Express, September 15, 2017. Accessed December 1, 2017: http://www.financialexpress.com/industry/technology/whatsappbusiness-app-goes-live-how-to-get-bookmyshow-movie-ticketsconfirmation-on-mobile/856744/

Gartner, W. B. 1985. A Conceptual Framework for Describing the Phenomenon of New Venture Creation. Academy of Management Review, 10(4): 696-706.

http://www.jstor.org/stable/258039

Goyal, S., McCord, M., \& Kapoor, A. 2017. Transforming Business Models in Fast-Emerging Markets-Lessons from India. Thunderbird International Business Review, 59(1): 23-32. http://doi.org/10.1002/tie.21750

Jones-Evans, D. 1995. A Typology of Technology-Based Entrepreneurs: A Model Based on Previous Occupational Background. International Journal of Entrepreneurial Behaviour \& Research, 1(1): 26-47. https://doi.org/10.1108/13552559510079751
Karlesky, M. J. 2015. Identifying Entrepreneurial Opportunities: Cognition and Categorization in Nascent Entrepreneurs. Doctoral Dissertation. Ann Arbor, MI: University of Michigan. https://deepblue.lib.umich.edu/handle/2027.42/116674

Knight, F. H. 1964. Risk, Uncertainty and Profit. New York: Courier Dover Publications.

Leyden, D. P., \& Link, A. N. 2015. Public Sector Entrepreneurship: US Technology \& Innovation Policy. New York: Oxford University Press.

Majumdar, S. K., Vora, D., \& Nag, A. K. 2010. Industry Structure Characteristics and International Entrepreneurship in India's Software Industry. The Journal of Entrepreneurship, 19(2): 109-136. https://doi.org/10.1177/097135571001900202

Nambisan, S. 2017. Digital Entrepreneurship: Toward a Digital Technology Perspective of Entrepreneurship. Entrepreneurship Theory and Practice, 41(6): 1029-1055. http://doi.org/10.1111/etap.12254

Nexus. 2015. Craftsvilla.com Raises $100 \mathrm{Cr}$ to Become the Ethnic Destination for India. Nexus Venture Partners, April 23, 2015. Accessed December 1, 2017: https://nexusvp.com/press-releases/craftsvilla-com-raises-100crto-become-the-ethnic-destination-for-india/

Noel, S., \& Banerjee, B. 2014. Global Entrepreneurship Monitor 2013: India Report. London: Global Entrepreneurship Research Association.

Prabhu, J., \& Jain, S. 2015. Innovation and Entrepreneurship in India: Understanding Jugaad. Asia Pacific Journal of Management, 32(4): 843-868. https://doi.org/10.1007/s10490-015-9445-9

Prahalad, C. K., \& Hamel, G. 1990. The Core Competence of the Corporation. Harvard Business Review, 68: 79-91.

Rainer, H., \& Walsh, S. T. 2015. An Introduction to the Field of Technology Entrepreneurship: Editorial to the Special Issue. Creativity \& Innovation Management, 24(4): 552-557. http://doi.org/10.1111/caim.12159

Ratinho, T., Harms, R., \& Walsh, S. T. 2015. Structuring the Technology Entrepreneurship Publication Landscape: Making Sense out of Chaos. Technological Forecasting \& Social Change, 100: $168-175$. https://doi.org/10.1016/j.techfore.2015.05.004

Sarasvathy, S. D. 2001. Causation and Effectuation: Toward a Theoretical Shift from Economic Inevitability to Entrepreneurial Contingency. Academy of Management Review, 26(2): 243-263.

Schumpeter, J. A. 1974. Capitalism, Socialism and Democracy. London: Unwin University Books.

Shane, S. 2000. Prior Knowledge and the Discovery of Entrepreneurial Opportunities. Organization Science, 11(4): 448-469. https://doi.org/10.1287/orsc.11.4.448.14602

Shane, S., \& Venkataraman, S. 2000. The Promise of Entrepreneurship as a Field of Research. Academy of Management Review, 25(1): 217-226. http://doi.org/10.5465/AMR.2000.2791611

Shane, S., \& Venkataraman, S. 2003. Guest Editors' Introduction to the Special Issue on Technology Entrepreneurship. Research Policy, 32(2): 181-184. https://doi.org/10.1016/S0048-7333(02)00104-X 


\section{Technology Entrepreneurship in Emerging Markets: An Exploration of Entrepreneurial Models Prevalent in India Shiv S Tripathi and Mita Brahma}

Singh, D. 2017. Key Innovations to Increase Adaptability of AI in Workplaces. People Strong, November 14, 2017. Accessed December 1, 2017:

https://www.peoplestrong.com/key-innovations-to-increaseadaptability-of-ai-in-workplaces/

Spiegel, M., \& Marxt, C. 2011. Defining Technology Entrepreneurship. Paper presented at the 2001 Industrial Engineering and Engineering Management Conference (IEEM), Singapore.

The Hindu Business Line. 2017. To Scale Up On-demand Movie Platform Vkaao, PVR Partners BookMyShow. The Hindu Business Line, November 15, 2017. Accessed December 1, 2017 : http://www.thehindubusinessline.com/info-tech/to-scale-upondemand-movie-platform-vkaaopvr-partners-

bookmyshow/article9962122.ece

Tzu-Hsin, L., Chu, Y.-Y., Hung, S.-C., \& Wu, S.-Y. 2005. Technology Entrepreneurial Styles: A Comparison of UMC and TSMC. International Journal of Technology Management, 29(1/2): 92-115. https://doi.org/10.1504/IJTM.2005.006006

Planning Commission of India. 2018. Approach Paper to the 12th Five Year Plan: Technology and Innovation. Government of India Planning Commission. Accessed December 1, 2017: http://12thplan.gov.in/forum_description.php?f=13.

Thomas, A., \& Bhattacharya, A. 2017. BankBazaar Co-founder Adhil Shetty's Paperless Future May Be Here. Economic Times, April 6, 2017. Accessed December 1, 2017:

https://economictimes.indiatimes.com/smallbiz/entrepreneurship/bankbazaar-co-founder-adhil-shettyspaperless-future-may-be-here/articleshow/58040583.cms

Thomas, P. M. 2013. Ferns N Petals Aims to Go Global. Forbes India, September 19, 2013. Accessed December 1, 2017:

http://www.forbesindia.com/article/work-in-progress/ferns-npetals-aims-to-go-global/36113/1

Thukral, I. S., Von Ehr, J., Walsh, S., Groen, A. J., Van Der Sijde, P., \& Akmaliah Adham, K. 2008. Entrepreneurship, Emerging Technologies, Emerging Markets. International Small Business Journal, 26(1): 101-116.

https://doi.org/10.1177/0266242607084656

UNESCO. 2018. Research and Development Expenditure (\% of GDP). United Nations Educational, Scientific, and Cultural Organization (UNESCO) Institute of Statistics. Accessed January 22, 2018: https://data.worldbank.org/indicator/GB.XPD.RSDV.GD.ZS.

Walsh, S. T., \& Linton, J. D. 2011. The Strategy-Technology Firm Fit Audit: A Guide to Opportunity Assessment and Selection. Technological Forecasting and Social Change, 78(2): 199-216. https://doi.org/10.1016/j.techfore.2010.06.023

Williamson, O. E. 2005. Transaction Cost Economics and Business Administration. Scandinavian Journal of Management, 22(1): 19-40.

https://doi.org/10.1016/j.scaman.2005.02.002

Your Story. 2017. BookMyShow Acquires Burrp in All-Cash Deal. Your Story, July 3, 2017. Accessed December 1, 2017:

https://yourstory.com/2017/07/bookmyshow-burrp-network18foodfesta-wellcare-ticketgreen-eventifier-paytm-alibaba-pictures/

\section{About the Authors}

Shiv S Tripathi is an Assistant Professor in the area of Strategic Management at the Management Development Institute in Gurgaon, India. He holds a $\mathrm{PhD}$ degree from the Vinod Gupta School of Management at the Indian Institute of Technology in Kharagpur. He has published papers in the area of product and service innovations, growth strategies, and innovations in large organizations. He has coauthored a book titled International Business along with a number of case studies. He is a member of the Strategic Management Society, the International Society for Professional Innovation Management, the Academy of Management, and the Academy of International Business. His current research interests include corporate entrepreneurship, open innovation, ambidexterity, and innovation in large organizations.

Mita Brahma is a Fellow Program Scholar in the area of Strategic Management at the Management Development Institute in Gurgaon, India. She holds MS and MBA degrees from the Indian Institute of Technology in Delhi, India. Her research interests include corporate entrepreneurship, innovation, and strategic human resources management. She has over thirty years of experience in the banking, software, and education sectors. She currently leads a niche-consulting firm that helps organizations improve their performance through increased operational efficiency and strategic and human resource initiatives.

Citation: Tripathi, S. S., \& Brahma, M. 2017. Technology Entrepreneurship in Emerging Markets: An Exploration of Entrepreneurial Models Prevalent in India.

Technology Innovation Management Review, 8(1): 24-32. http://doi.org/10.22215/timreview/1131

Keywords: technology, entrepreneurship, models, typology, emerging markets, India 


\section{Academic Affiliations and Funding Acknowledgements}

Canadà
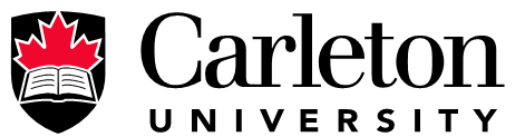

U N I V E R S I T Y

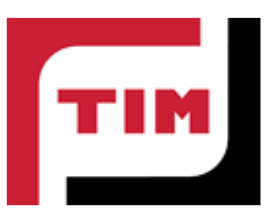

The Federal Economic Development Agency for Southern Ontario (FedDev Ontario; feddevontario.gc.ca) is part of the Innovation, Science and Economic Development portfolio and one of six regional development agencies, each of which helps to address key economic challenges by providing regionallytailored programs, services, knowledge and expertise.

- The TIM Review receives partial funding from FedDev Ontario's Investing in Regional Diversification initiative.

Technology Innovation Management (TIM; timprogram.ca) is an international master's level program at Carleton University in Ottawa, Canada. It leads to a Master of Applied Science (M.A.Sc.) degree, a Master of Engineering (M.Eng.) degree, or a Master of Entrepreneurship (M.Ent.) degree. The objective of this program is to train aspiring entrepreneurs on creating wealth at the early stages of company or opportunity lifecycles.

- The TIM Review is published in association with and receives partial funding from the TIM program. 